\title{
The amelioration of T2DM rat femoral bone achieved by anti-osteoporosis of caprine CSN1S2 protein through bone morphogenetic protein signaling pathway
}

\author{
Fatchiyah Fatchiyah1,2®, Bambang Setiawan ${ }^{3}$, Tomohiko Sasase ${ }^{4}$ and Takeshi Ohta 5 \\ 1Research Center of Smart Molecule of Natural Genetics Resource, Brawijaya University, Malang, East Java, Indonesia; 2Department of Biology, \\ Faculty of Mathematics and Natural Sciences, Brawijaya University, Malang, East Java, Indonesia; '3Department of Biochemistry and Molecular \\ Biology, Medical Faculty, Lambung Mangkurat University, Banjarmasin, South Kalimantan, Indonesia; ${ }^{4 B i o l o g i c a l / P h a r m a c o l o g i c a l ~ R e s e a r c h ~ L a b o-~}$ \\ ratories, Central Pharmaceutical Research Institute, Japan Tobacco Inc., Osaka, Japan; ${ }^{5}$ Graduate School of Agriculture, Kyoto University, Kyoto, \\ Japan
}

We investigated the potential anti-glycation and antiosteoporosis properties of Caprine milk CSN1S2 protein on the serum AGEs and sRAGE level, osteogenic factors expressions, femoral bone mesostructure, histomorphometry, and hydroxyapatite crystals changes in T2DM rats. Varying doses of Caprine milk CSN1S2 protein (0, 375,750 , and $1500 \mathrm{mg} / \mathrm{kg} \mathrm{BW}$ ) were used to treat the control and T2DM rats. We measured AGEs and SRAGE level; RUNX2, OSX, BMP2, and Caspase-3 expressions in rats using ELISA and immunohistochemistry, respectively. The mesostructure and histomorphometry of femoral bone was analyzed using SEM Microscope and BoneJ software, then hydroxyapatite crystal size was determined using SEM-XRD. T2DM rats showed a high level of AGEs and a low level of SRAGE, the RUNX2, OSX, and BMP2 expression was down regulated, BV, BV.TV, Tb.Th, Tb.Sp, increased and SMI levels declined, respectively. Vice versa, after administration of the CSN1S2 protein to T2DM rats, improvement in all levels of molecular and cellular markers was achieved. In the CSN1S2 highest dose, AGEs level declined and sRAGE level elevated in T2DM rats. The 375 and $750 \mathrm{mg} / \mathrm{kgBW}$ of CSN1S2 protein was able to upregulate the RUNX2, OSX, and BMP2 expression in T2DM rats, thus improving the normalization of osteoclasts and osteoblasts number. The whole dose of CSN1S2 triggered the thickening of trabecular bone wall, granule formation, and normalized the trabecular thickness (Tb.Th) parameter of T2DM rats. The hydroxyapatite crystal size was increased in the highest dose of CSN1S2-treated T2DM rats. This study indicated that CSN1S2 protein had a protective effect against osteoporosis in the T2DM rat bones by means of glycation pathway inhibition, bone histomorphometry and mesostructure improvement via bone morphometric protein signaling.

Keywords: AlphaS2-casein, bone, diabetes, BMP signaling; mesostructure, osteoporosis

Received: 24 November, 2020; revised: 06 January, 2021; accepted: 14 April, 2021; available on-line: 09 May, 2021

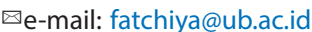

Acknowledgements of Financial Support: This study was supported by national research grant from Directorate Higher Education, Republic Indonesia Ministry of Education and Culture. No. Research Contract of PDUPT-DRPM research grant: 332.6/UN10. C10/PN/2019 and PTUPT-DRPM research grant: 127/SP2H/LT/ DRPM/2020/09.3.2020.

Abbreviations: AGEs, Advanced Glycation End Products; ANOVA, Analysis of variance; BMP, Bone Morphogenetic Proteins; BV, Bone Volume; CSN1S2, Casein alpha-S2; ELISA, Enzyme-Linked Immuno- sorbent Assay; H\&E, Hematoxylin and Eosin; HRP, Horseradish peroxidase; OSX, Osterix; PBS, Phosphate Buffer Saline; RUNX2, RuntRelated Transcription Factor 2; SEM, Scanning Electron Microscope; SMI, Structure Model Index; sRAGE, Soluble circulating RAGE; STZ, Streptozotocin; T2DM, Type 2 Diabetes Mellitus; Tb.Sp, Trabecular Separation; Tb.Th, Trabecular Thickness; TV, Trabecular Bone Volume; XRD, X-ray Diffraction

\section{INTRODUCTION}

Type 2 diabetes mellitus (T2DM) is a metabolic disease caused by insulin secretion abnormality that induces hyperglycemia. Hyperglycemia is a major factor in microvascular and macrovascular complications in diabetes mellitus. This complication may take place via the polyol pathways, dysregulation of protein kinase c, hexosamine pathways, and advanced glycation end products (AGEs) (Gateva et al., 2019). The AGEs are diverse compounds formed by non-enzymatic glycation reactions of proteins, lipids, and nucleic acids. The glycation reaction includes several stages, namely the reversible bond between the carbonyl group of reducing sugar and the amino-terminal group of proteins, lipids, or nucleic acids forming the Schiff base. The rearrangement of the Schiff base will establish more stable ketoamines, which are called Amadori products. These products have structural changes through oxidation, dehydration, and degradation to produce AGEs compound with high stability (Stirban et al., 2014).

The interaction of AGEs and the AGEs receptor (RAGEs) plays an important role in the diabetes complications pathway (Devangelio et al., 2007). In patients with T2DM, there was no increase in serum AGEs and trabecular bone AGEs level compared to control. However, cortical bones AGEs levels were elevated significantly compared to control (Karim et al., 2018). Accumulated AGEs in bones will bind to their receptors in osteoblasts and osteoclasts. AGEs-RAGE binding will increase osteoclast activity and reduce osteoblast activity thereby contributing to resorption and bone fragility (Okazaki \& Yamaguchi, 2012; Willett et al., 2014). The osteoblastogenesis is initiating by the bone morphogenetic proteins (BMPs) signaling pathway, which is a fundamental role in bone formation and development. Dysregulation of BMP signal transduction causes the bone disorder on skeletal differentiation and development (Wu et al., 2016). Moreover, the BMPs have a positive effect on chondrogenesis and cartilage formation through SMAD-dependent signaling (Thielen et al., 2019). The BMPs stimulated the expression of runt-related tran- 
scription factor 2 (RUNX2) and osterix (OSX) capable of inducing the differentiation of mesenchymal cells into osteoblasts (Hie et al., 2011). The BMPs, RUNX2, and OSX expressions are affected by the increasing of AGEs levels in high glucose-treated human osteoblasts and diabetic rats (Miranda et al., 2016; Picke et al., 2019; Wu et al., 2019).

In general, the dimensions, mineral density, and microarchitecture measurements characterized bone quality. All these factors are influenced by the rate of bone turnover (Seeman \& Delmas, 2006). The relationship between bone mineral density and T2DM is unclear. There is an increase, decrease, or no change in bone volume in T2DM (Adil et al., 2015; Issa et al., 2011; Takizawa et al., 2003). Cortical T2DM was found to increase porosity (Kazakia et al., 2010; Campbell et al., 2016), the effect on the trabecular was unknown and would be assessed in this study. In patients with type 2 diabetes, there is an increase in trabecular thickness (Kazakia et al., 2010). High fat diet administrated-rats develop an insulin resistance causing lowered compact bone and stiffness that associated with bone fragility (Yamanaka et al., 2018). Skeletal fragility is a major complication of T2DM. Nevertheless, the mechanism of skeletal fragility is still not understood. Increased risk of fracture is deemed to be an effect of microarchitecture worsening or poor bone quality caused by the AGEs accumulation. There is still controversy about the role of AGEs in bone. In the ex vivo study, there was a negative correlation between AGEs with ultimate strains and stress of cortical and trabecular bone (Nyman et al., 2007; Karim \& Vashishth, 2012). Previous studies had found no association between AGEs and trabecular biomechanical properties (Burt-pichat et al., 2011). Serum AGEs correlate with AGEs in trabecular bone (Karim et al., 2018). Other studies proved that the AGEs accumulation can alter the bone organic matrix, trigger growth and crack propagation (Poundarik et al., 2015). Osteoclasts resorption activities were correlated with the in situ concentration of AGEs positively (Dong et al., 2011). However, there are still opposing opinions among their research.

The AGE-RAGE interaction blockade can be achieved by soluble RAGE (sRAGE), which is naturally produced by alternative splicing of RAGE mRNA. The SRAGE is a splice variant of the full-length receptor. The sRAGE circulates in the plasma naturally and represent as an enticement to inhibit the binding of AGEsRAGE (Devangelio et al., 2007). The T2DM patients had significantly lower levels of plasma sRAGE than control (Abdulle et al., 2019). The diabetes animal model also demonstrated a decrease of sRAGE levels (Hsia et al., 2016). On the contrary, several studies had investigated the existence of sRAGE levels increase in T2DM (Kerkeni et al., 2012). The sRAGE is protective in preventing bone loss in alveolar diabetic mice (Lalla et al., 2000).

The emergence of AGEs is an important factor in diabetes so that the strategies development against AGEs has been in the center of scientific interest. The strategies include developing substances such as the AGE formation inhibitor, AGE breakers, and nutraceuticals as well (Gkogkolou \& Böhm, 2012). Goat milk contains alpha-S2 casein (CSN1S2) protein that has a lot of biological function potency to control some mechanisms. Our previous research found that CSN1S2 has a wide range of food safety (Agustina et al., 2015) and has potential as a therapeutic agent in the diabetic rat model at the level of a molecular mechanism (Fatchiyah et al., 2020). It has an anabolic effect on bone through a crystallization mechanism and mesostructure improvement in the rat rheumatoid arthritis model. It is able to modulate RAGE expression as well (Bia et al., 2015; Fatchiyah et al., 2015). Moreover, CSN1S2 is capable of triggering proliferation in pre-osteoblast cells induced by methylglyoxal (Chotimah et al., 2015). We predict that Caprine CSN1S2 protein functions as a functional protective food to control the mechanism pathway related to the bone fragility, as anti-glycation, and anti-osteoporosis. Therefore, this study focused to analyze the role of CSN1S2 in the glycation pathway, mesostructure, histomorphometry, and hydroxyapatite crystal changes in T2DM rat femoral bone.

\section{MATERIALS AND METHODS}

\section{Preparation of CSN1S2 protein from Ethawah crossbred goat milk}

The Ethawah crossbred goat milk $(250 \mathrm{~mL})$ was heated to the temperature of $40^{\circ} \mathrm{C}$, followed by the addition of glacial acetic acid $(5 \mathrm{~mL})$ until precipitate formed. Protein was filtered using nylon membranes to obtain the precipitate. The protein obtained was quantified by the UV-Vis NanoDrop spectrophotometer. The protein was stored at $-20^{\circ} \mathrm{C}$ for subsequent analysis. The $36 \mathrm{kDa}$ CSN1S2 protein was isolated and cut from SDS-PAGE gel and then purified using the previous protocol (Bia et al., 2015). Purified-CSN1S2 protein was stored at $-20^{\circ} \mathrm{C}$ until used.

\section{T2DM rat model establishment}

In this study, we used forty-three-month-old adult male rats (Rattus norvegicus) of the Wistar strain, weighing 100-150 grams, acclimated to laboratory conditions for a week. The experimental animals were obtained from Integrated Research and Testing Laboratory, Gadjah Mada University, Yogyakarta, Indonesia. The rats were given standard diet which contained cornstarch, wheat bran, palm oil, essential amino acids, minerals, and vitamins (Comfeed PARS, JAPFA Comfeed Indonesia, Tbk.). This standard diet was given during the acclimatization period and during the research process in T2DM and control rats (normal rats). To make the twelve of T2DM rats' model, the T2DM rats were established by high cholesterol (45-50\% standard diet, 20-30\% wheat flour, $3-6 \%$ duck egg yolk, 10-20\% goat fat, 2-3\% coconut oil, $0.1-0.5 \%$ cholic acid) feeding for 2 months until they had hypercholesteremia (cholesterol levels >200 mg/dl). Then, the positive high-cholesterol rats were injected with $25 \mathrm{mg} / \mathrm{kg}$ BW of streptozotocin (STZ) intraperitoneally. After the STZ injection, blood glucose levels were monitored every 2 weeks. DM is diagnosed when blood sugar exceeds $250 \mathrm{mg} / \mathrm{dl}$ (Moree et al., 2013). The blood glucose and cholesterol parameters were evaluated by NescoMultiCheck (bioptik Technology, Taiwan).

\section{The treatment of CSN1S2 protein in the experimental rat}

The forty rats were divided into 8 groups with 5 rats per each group. The groups include 4 groups of control (C) rats and 4 groups of T2DM (DM) rats. We treated the control and T2DM rats with several doses of Caprine milk CSN1S2 protein (0, 375, 750, and $1500 \mathrm{mg} / \mathrm{kg}$ $\mathrm{BW})$. Therefore, there were eight groups of experiment: control rat group without adding CSN1S2 protein (C), control rat group receiving $375 \mathrm{mg} / \mathrm{kg}$ BW of CSN1S2 protein (CM375), control rat group receiving $750 \mathrm{mg} / \mathrm{kg}$ 
BW of CSN1S2 protein (CM750), control rat group receiving $1500 \mathrm{mg} / \mathrm{kg} \mathrm{BW}$ of CSN1S2 protein (CM1500), T2DM rat group without adding the CSN1S2 protein (DM), T2DM rat group receiving $375 \mathrm{mg} / \mathrm{kg}$ BW of CSN1S2 protein (DMM375), T2DM rat group receiving $750 \mathrm{mg} / \mathrm{kg} \mathrm{BW}$ of CSN1S2 protein (DMM750), and T2DM rat group receiving $1500 \mathrm{mg} / \mathrm{kg}$ BW of CSN1S2 protein (DMM1500). The CSN1S2 protein treatment was carried out orally (by oral gavage) one treatment per dose for 28 days.

\section{Surgical technique and organ isolation}

Euthanasia was performed using the standard protocol (Fatchiyah et al., 2006). The dead rats were dissected to obtain the tissue samples, including the femoral bone samples. Then, the femoral bone was incubated at $4 \%$ paraformaldehyde min. $24 \mathrm{~h}$. After that, the femoral bone was embedded on paraffin block. The embedded bone tissue was cut by microtome around $5 \mu \mathrm{m}$ and the bone tissue pieces were placed on histological slide.

\section{AGEs and sRAGE analysis}

The serum level of AGEs and sRAGE expressions were measured by Sandwich-ELISA method. We used ELISA assay kit (Elabscience Biotechnology, Sydney) and anti-rat AGEs and sRAGE antibodies (Bioassay Technology Laboratory, China). The analysis was carried out according to the kit protocol.

\section{Histopathological and immunohistochemistry analysis}

The histopathological profile of femoral bone tissue was observed from the hematoxylin and eosin (H\&E) stained tissue section. The double staining immunohistochemistry was performed to analyze the RUNX2, OSX, BMP2, and Caspase-3 expressions in femoral bone (Fatchiyah et al., 2006). The tissue sections were deparaffinized in xylene and rehydrated in graded alcohol, then washed in PBS $\mathrm{pH}$ 7.4. After blocking with $2 \%$ skim milk for 1 hour, the sections were incubated with the first primary antibody for 1 hour in room temperature. The first primary antibodies used were the mouse antiRUNX2 (Santa Cruz Biotechnology, USA with 1:1000 dilution) and mouse anti-BMP2 (Bioss, USA with 1:1000 dilution) in $1 \%$ skim milk. The sections were washed with PBS ( $\mathrm{pH}$ 7.4) three times. They were incubated with the second primary antibody overnight at $4^{\circ} \mathrm{C}$, and then washed in PBS (pH 7.4). The second primary antibodies used were the rabbit anti-OSX (Bioss, USA with 1:1000 dilution) and mouse anti-Caspase-3 (Santa Cruz Biotechnology, USA with 1:1000 dilution) in 1\% skim milk. The sections were incubated with the following secondary antibodies: HRP-labelled goat anti-mouse IgG (1:1500) and AP-labels goat anti-rabbit IgG at room temperature for 1 hour and washed with PBS ( $\mathrm{pH} 7.4)$. The sections were incubated with $\mathrm{DAB}$ and LV Blue substrate and washed in PBS $\mathrm{pH}$ 7.4. The femoral bone tissue sections were visualized and analyzed using light microscope FSX-100 (Olympus) with $200 \times$ magnifications. The osteoblast and osteoclast number were counted and the RUNX2, OSX, BMP2, and Caspase-3 expression levels were measured by FSX-BSW software.

\section{Femoral bone mesostructure}

The rat femoral bones were cut to size $2 \times 2 \times 1$ millimeter, then immediately immersed in $2 \%$-glutaraldehyde in a $0.1 \mathrm{M}$ cacodylate buffer $(\mathrm{pH} 7.4)$ at $4^{\circ} \mathrm{C}$ for 4 hours. They were decalcified with 5\% EDTA and $0.2 \mathrm{M}$ sucrose $\left(\mathrm{pH} \mathrm{7.4)}\right.$ at $4^{\circ} \mathrm{C}$ for 48 hours. The post-fixation was done in osmium tetroxide $1 \%$ in a $0.1 \mathrm{M}$ cacodylate buffer ( $\mathrm{pH}$ 7.4). The bones were dehydrated and immersed in Luveak 812 resin. We used ultramicrotome to generate the bone sections of 70-80 nanometers thickness. The sections were stained with uranium acetate and lead citrate, then they were observed using Scanning Electron Microscopy (SEM) at the Physics Laboratory and Central Laboratory of Faculty of Science, Malang State University, Malang, Indonesia (Noor \& Setiawan, 2013).

\section{Femoral bone histomorphometry}

Histomorphometry measurements of femoral bones were performed according to the previous study methods (Parfitt et al., 1987). The femur mesostructure analysis was performed at $70-80 \times$ magnifications. BoneJ software was used for histomorphometry analysis. There were several parameters measured in this study, including the bone volume (BV), trabecular bone volume (TV), trabecular thickness ( $\mathrm{Tb}$. Th), trabecular separation ( $\mathrm{Tb}$. $\mathrm{Sp}$ ), and structure model index (SMI). All formulas, symbols, units, and nomenclature were based on the guidelines from the American Society for Bone and Mineral Research (ASBMR) Histomorphometry Nomenclature Committee (Hofbauer et al., 2007).

\section{Femoral bone hydroxyapatite crystals}

Analysis of bone hydroxyapatite crystals was carried out as in the previous study. The bone ash was made by heating in $800^{\circ} \mathrm{C}$ for 2 hours with a muffle furnace (Hayatullina et al., 2012). We performed the characterization of the X-ray diffraction (XRD) of T2DM and control bone using PANalyticalX'Pert PRO-MPD. High Score Plus, Crystal Maker, and DDVIEW complemented with the latest version of PDF2 were utilized for subsequent analysis. Diffraction spectra were recorded at an angle of $2 \theta$, from $20^{\circ}$ to $60^{\circ}$, with a $\mathrm{Cu} \mathrm{K} \alpha$ radiation source (wavelength $=1.54056 \mathrm{~A}^{\circ}, 40 \mathrm{~mA}, 40 \mathrm{kV}$ ) and step size of $0.05^{\circ}$. The average sizes of apatite crystals in various groups were evaluated by the Scherrer equation. Rietveld refinement analysis was obtained from detailed spectra of T2DM and control apatite samples (Noor \& Setiawan, 2013).

\section{Ethics}

This study had been evaluated and approved by the Research Ethics Committee of Brawijaya University, Malang, and East Java, Indonesia (Certificate number, 417-KEP-UB).

\section{Statistical Analysis}

All data were tabulated, presented as mean \pm standard deviation and group differences were analyzed by ANOVA followed by Duncan test with $P$ value $<0.05$ (SPSS 16.0 Inc., Chicago, Illinois, USA). The significance of $P<0.05$ was concluded to be statistically significant.

\section{RESULTS}

\section{The level of AGEs and expression of sRAGE in serum samples}

The changes of AGEs level and sRAGE expression in CSN1S2-treated rats are shown in Fig. 1. A reduction of serum AGEs level took place in the control rats treated 

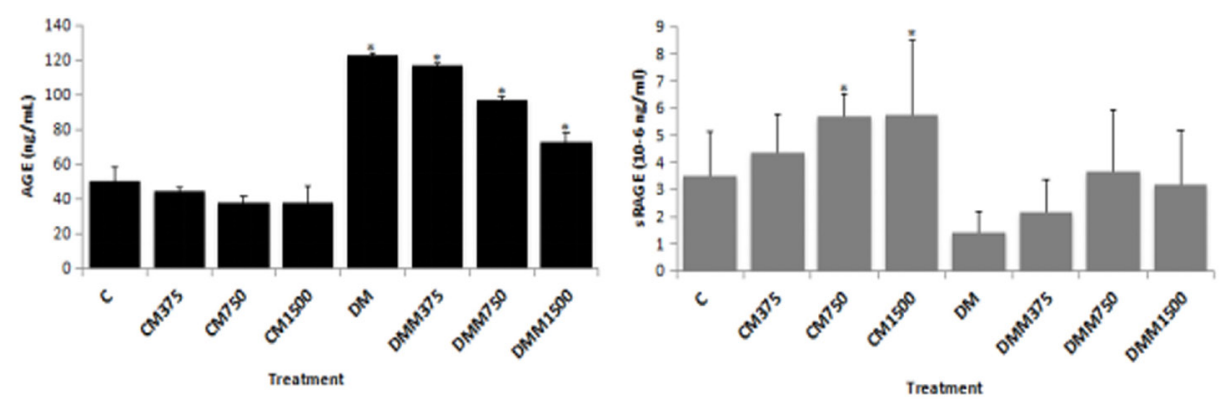

Figure 1. The serum AGEs levels and sRAGE expression in various rat groups by ELISA: (a) AGEs; (b) sRAGE.

All groups were analyzed using ANOVA followed by Tukey test with a value of $P<0.05 .{ }^{*}=$ The significant difference compares with all rat groups. C: control rat group receiving $0 \mathrm{mg} / \mathrm{kg}$ BW of CSN1S2 protein, CM375: control rat group receiving $375 \mathrm{mg} / \mathrm{kg}$ BW of CSN1S2 protein; CM750: control rat group receiving $750 \mathrm{mg} / \mathrm{kg}$ BW of CSN1S2 protein; CM1500: control rat group receiving $1500 \mathrm{mg} / \mathrm{kg}$ BW of CSN1S2 protein; DM: T2DM rat group receiving $0 \mathrm{mg} / \mathrm{kg}$ BW of CSN1S2 protein; DMM375: T2DM rat group receiving $375 \mathrm{mg} / \mathrm{kg}$ BW of CSN1S2 protein; DMM750: T2DM rat group receiving $750 \mathrm{mg} / \mathrm{kg}$ BW of CSN1S2 protein; DMM1500: T2DM rat group receiving $1500 \mathrm{mg} /$ $\mathrm{kg}$ BW of CSN1S2 protein.

with $375 \mathrm{mg} / \mathrm{kg} \mathrm{BW}, 750 \mathrm{mg} / \mathrm{kg} \mathrm{BW}$, and $1500 \mathrm{mg} / \mathrm{kg}$ $\mathrm{BW}$ of CSN1S2 protein. Diabetic rats turned out to have a significant rise in the serum AGEs level. This AGEs level was affected significantly by CSN1S2 protein administration. In this study, we investigated that the higher the dose of CSN1S2 protein given to diabetic rats, the lower the AGEs level. Hence, DMM1500 had the sharpest decrease in AGEs level. The Caprine CSN1S2 protein administration also had an impact on serum sRAGE expressions of rats. A significant increase of sRAGE expressions was observed in CM750 and CM1500 as compared to $\mathrm{C}$ group $(P<0.05)$. On the contrary to AGEs level, the sRAGE expression of diabetic rats declined. CSN1S2 protein administered-diabetic rats showed an up-regulated expression of serum sRAGE. The highest rise of sRAGE expression occurred in DMM750.

The expression of RUNX2, OSX, BMP2 and Caspase-3 in all rat groups were related to the osteoclast and osteoblast number

The expressions of RUNX2, OSX, and BMP2 were extremely down regulated in diabetic rats compared to the control (Fig. 2; Fig. 6). The CSN1S2 protein treatment reduced the expression of RUNX2, OSX, and BMP2 in control rats although that was not significant. A different effect of this protein administration occurred to the diabetic rats. Three kinds of CSN1S2 protein doses were able to raise the OSX and BMP2 expression in diabetic rats (Fig. 3D and 3E). Moreover, the BMP2 expression of DMM750 was similar to the one in the control rat. In the case of RUNX2 expression, only the $1500 \mathrm{mg} / \mathrm{kg} \mathrm{BW}$ of CSN1S2 protein had no effect on the diabetic rat. DMM375 and DMM750 had an up-regulated expression of RUNX2 (Fig. 3C). DM rat group resulted in the highest expression level of Caspase-3. In control rats, the administration of $375 \mathrm{mg} / \mathrm{kg}$ BW of CSN1S2 protein raised the Caspase-3 expression, while the $1500 \mathrm{mg} / \mathrm{kg}$ BW of CSN1S2 protein reduced it. CM750 had no change in its Caspase-3 expression compared to the C group. DMM375, DMM750, and DMM1500 showed a down-regulated expression of Caspase-3 (Fig. 3F).

The number of osteoclasts in Caprine CSN1S2 protein-treated control rats was not significantly different from the $\mathrm{C}$ group. The diabetic rats had a high number of osteoclasts. The administration of CSN1S2 protein at a dose of 375 and $750 \mathrm{mg} / \mathrm{kg}$ BW diminished the osteoclast number. However, the $1500 \mathrm{mg} / \mathrm{kg} \mathrm{BW}$ of

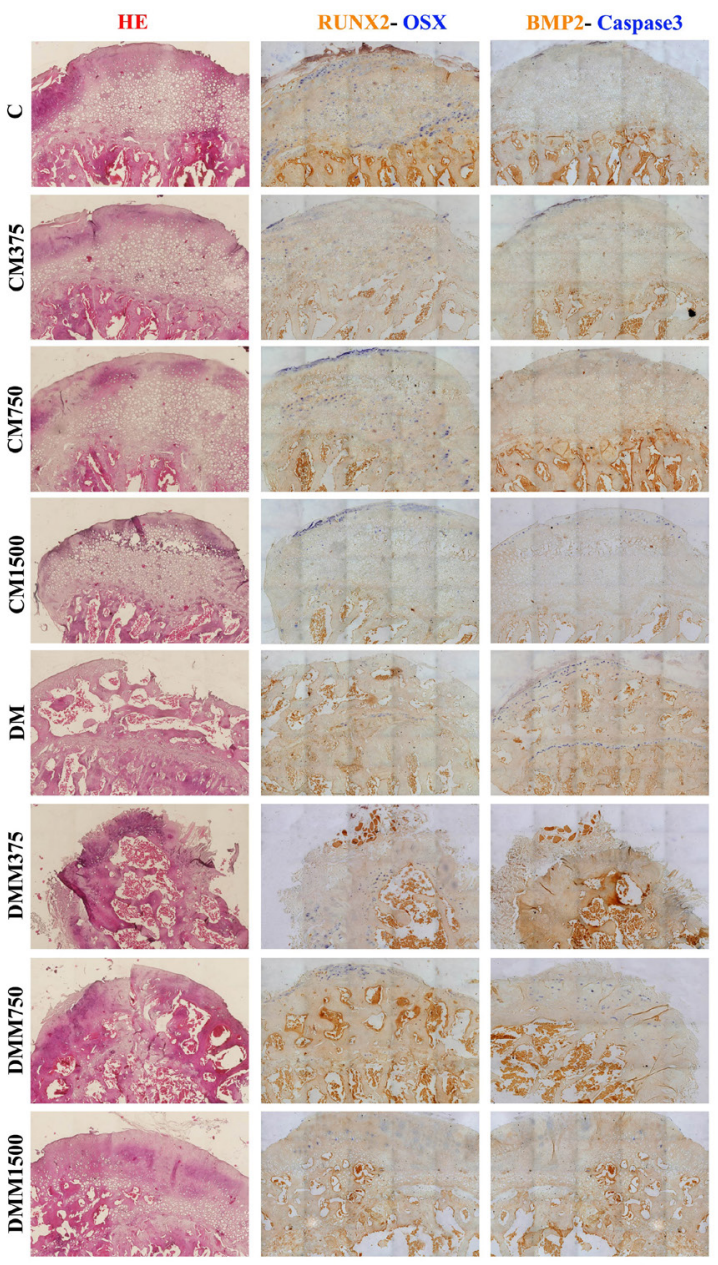

Figure 2. The RUNX2, BMP2 and OSX2 expression in femoral bone histology.

RUNX2 and BMP2 were labeled with DAB (brown color), OSX and Caspase-3 was labeled with LV blue. C: control rat group receiving $0 \mathrm{mg} / \mathrm{kg}$ BW of CSN1S2 protein, CM375: control rat group receiving $375 \mathrm{mg} / \mathrm{kg}$ BW of CSN1S2 protein; CM750: control rat group receiving $750 \mathrm{mg} / \mathrm{kg}$ BW of CSN1S2 protein; CM1500: control rat group receiving $1500 \mathrm{mg} / \mathrm{kg}$ BW of CSN1S2 protein; DM: T2DM rat group receiving $0 \mathrm{mg} / \mathrm{kg}$ BW of CSN1S2 protein; DMM375: T2DM rat group receiving $375 \mathrm{mg} / \mathrm{kg}$ BW of CSN1S2 protein; DMM750: T2DM rat group receiving $750 \mathrm{mg} / \mathrm{kg}$ BW of CSN1S2 protein; DMM1500: T2DM rat group receiving $1500 \mathrm{mg} / \mathrm{kg}$ BW of CSN1S2 protein. 
A)

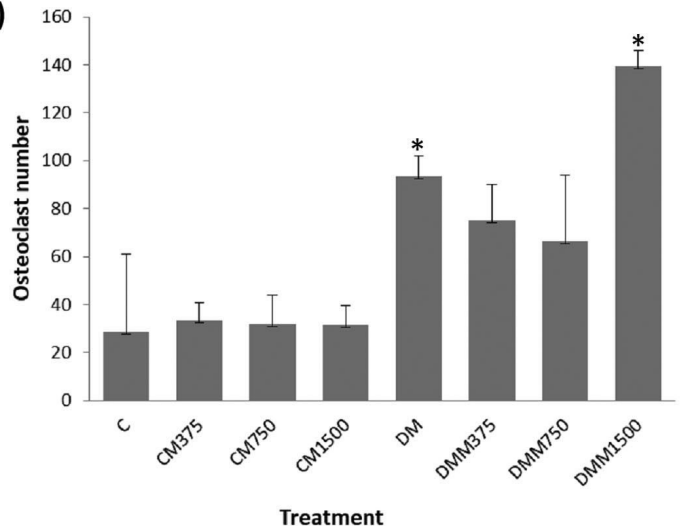

C)

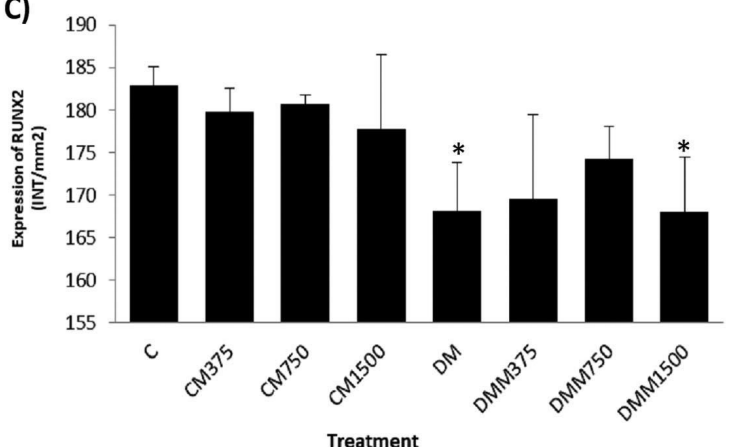

E)

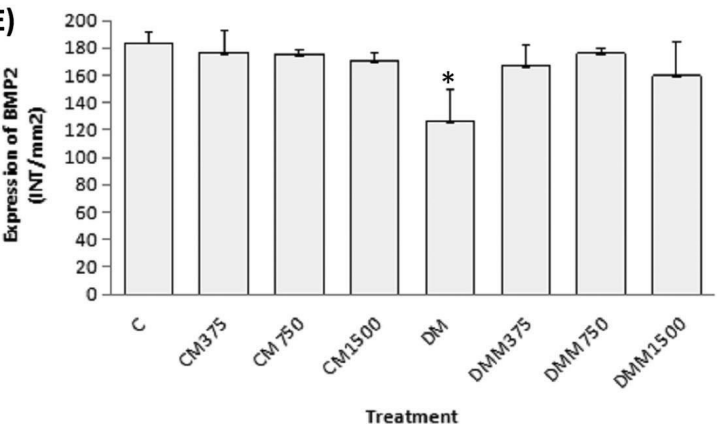

B)

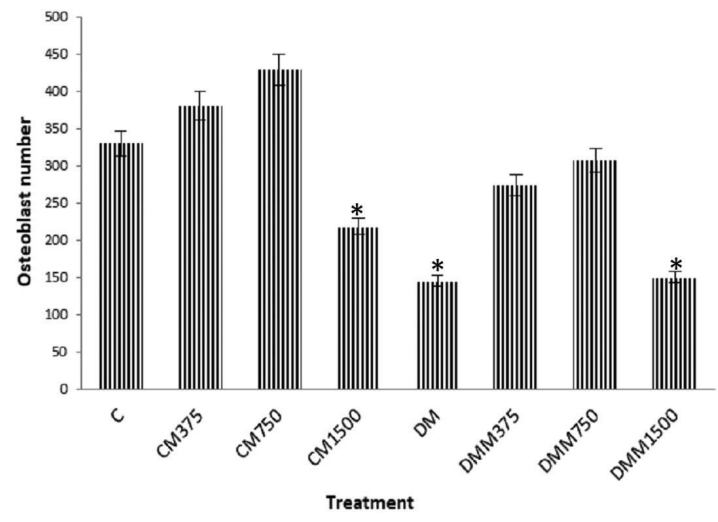

D)

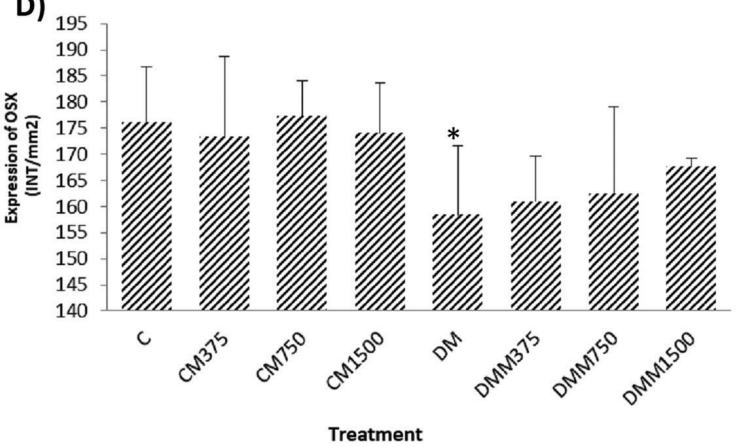

F)

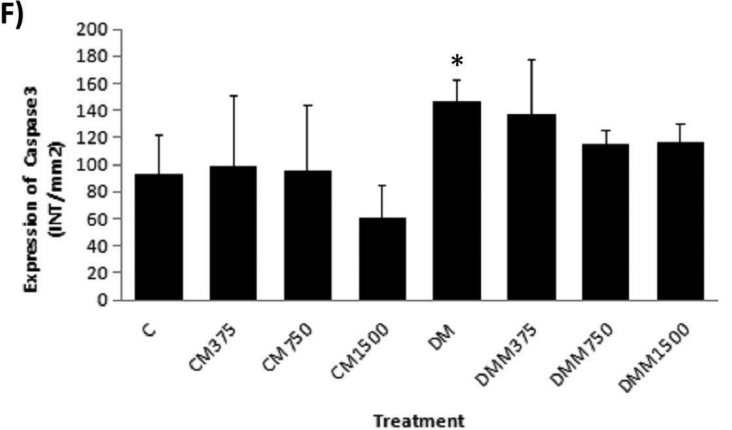

Figure 3. The cells number and expression level in osteogenic differentiation parameters.

A) Osteoclast number, B) Osteoblast number, C) Expression Level of RUNX2, D) Expression Level of OSX, E) Expression Level of BMP2, and F) Expression Level of Caspase-3. C: control rat group receiving $0 \mathrm{mg} / \mathrm{kg}$ BW of CSN1S2 protein, CM375: control rat group receiving $375 \mathrm{mg} / \mathrm{kg}$ BW of CSN1S2 protein; CM750: control rat group receiving $750 \mathrm{mg} / \mathrm{kg}$ BW of CSN1S2 protein; CM1500: control rat group receiving $1500 \mathrm{mg} / \mathrm{kg}$ BW of CSN1S2 protein; DM: T2DM rat group receiving $0 \mathrm{mg} / \mathrm{kg} \mathrm{BW}$ of CSN1S2 protein; DMM375: T2DM rat group receiving $375 \mathrm{mg} / \mathrm{kg}$ BW of CSN1S2 protein; DMM750: T2DM rat group receiving $750 \mathrm{mg} / \mathrm{kg}$ BW of CSN1S2 protein; DMM1500: T2DM rat group receiving $1500 \mathrm{mg} / \mathrm{kg}$ BW of CSN1S2 protein. The CSN1S2 protein-treated control rats, T2DM rats, and CSN1S2 protein-treated T2DM rats did statistical analysis of several parameters of osteogenic differentiation, using independent sample t-test at control rats. The significant of $P<0.05$ was concluded to be statistically significant.

CSN1S2 gave rise to the significant increase of diabetic rat's osteoclast number (Fig. 3A).

There was a high number of osteoblasts in the control rats. This number was significantly reduced in the condition of diabetes. Interestingly, the 375 and $750 \mathrm{mg} /$ $\mathrm{kg} \mathrm{BW}$ of CSN1S2 protein were able to elevate the osteoblast number both in control and diabetic rats. When the rats received $1500 \mathrm{mg} / \mathrm{kg}$ BW of CSN1S2 protein, their osteoblast number was decreased (Fig. 3B).

\section{Mesostructure of the femoral bone}

The mesostructure of femur bone was observed at $200 \times$ and $2000 \times$ magnification. The control rat with $0 \mathrm{mg} / \mathrm{kg}$ BW CSN1S2 protein treatment (C) had rodlike trabeculae, minimal holes, and no granules. The trabecular bone surface of the $\mathrm{C}$ group was similar to the stepladder pattern (Fig. 4.II). The administration of CSN1S2 $(375,750$, and $1500 \mathrm{mg} / \mathrm{kg} \mathrm{BW})$ to the control rats showed the thickening of the trabecular bone wall (Fig. 4.I). A flat trabecular bone surface without stepladder pattern was found in them. In addition, a high num- 


\section{The Entire Femoral Bone Mesostructure}

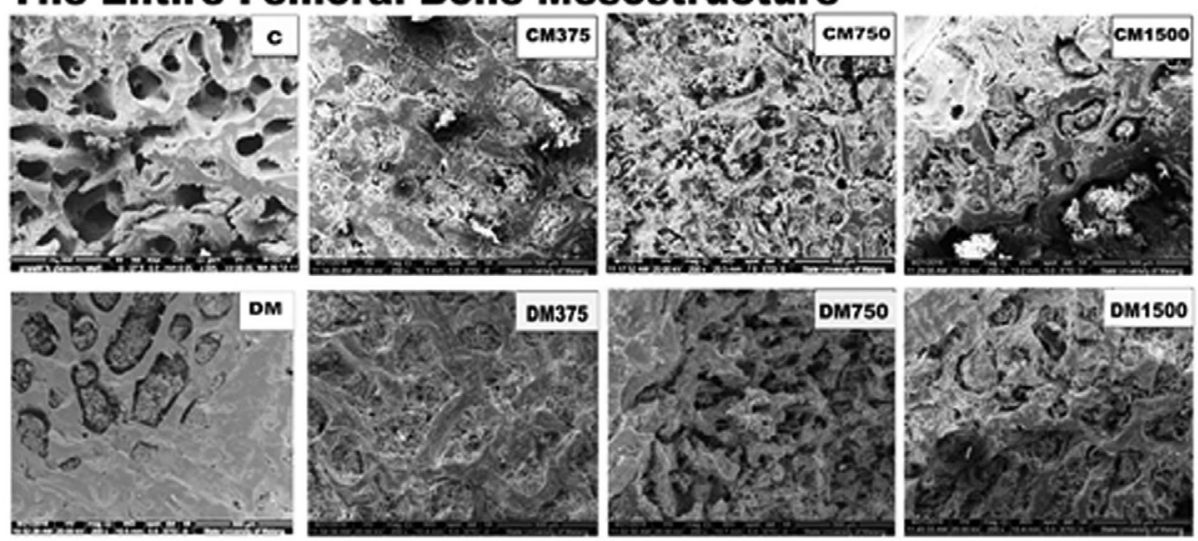

\section{The Topography of Trabecular Femoral Bone Surface}
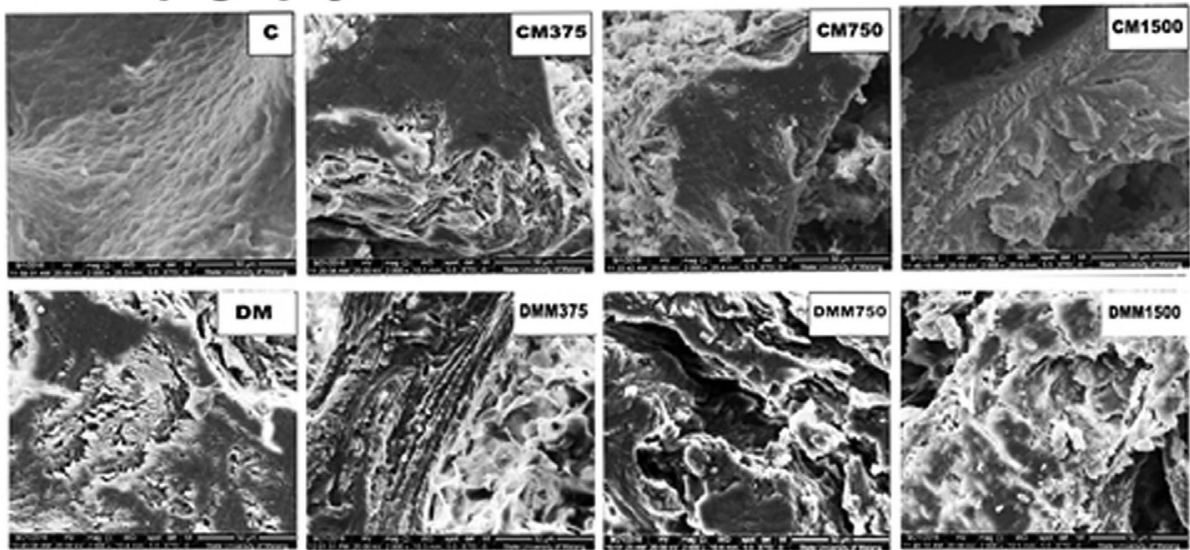

III. The Granule Improvement of Femoral Bone Mesostructure
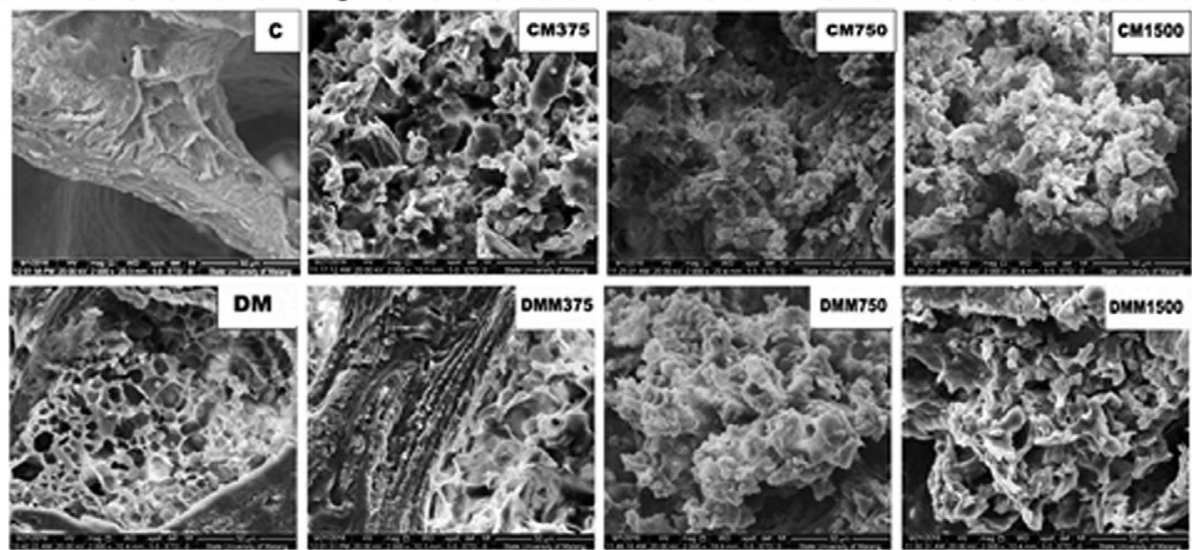

Figure 4. The mesostructure of femoral bone of rat shows the trabecular bone walls, topography of the trabecular bone surface, and holes containing granules.

I used 200x of magnification, and II \& III used 2000x of magnification of scanning electron microscope with $40 \mathrm{kV}$. C: control rat group receiving $0 \mathrm{mg} / \mathrm{kg}$ BW of CSN1S2 protein, CM375: control rat group receiving $375 \mathrm{mg} / \mathrm{kg}$ BW of CSN1S2 protein; CM750: control rat group receiving $750 \mathrm{mg} / \mathrm{kg}$ BW of CSN1S2 protein; CM1500: control rat group receiving $1500 \mathrm{mg} / \mathrm{kg}$ BW of CSN1S2 protein; DM: T2DM rat group receiving $0 \mathrm{mg} / \mathrm{kg}$ BW of CSN1S2 protein; DMM375: T2DM rat group receiving $375 \mathrm{mg} / \mathrm{kg}$ BW of CSN1S2 protein; DMM750: T2DM rat group receiving $750 \mathrm{mg} / \mathrm{kg}$ BW of CSN1S2 protein; DMM1500: T2DM rat group receiving $1500 \mathrm{mg} / \mathrm{kg}$ BW of CSN1S2 protein.

ber of granules were formed and fully filled in the holes of trabecular bone (Fig. 4.II and 4.III).

In diabetes mellitus rats, there was a thickening of the trabecular bone. The trabecular bone had a flat surface and cracks in several areas. Its holes were filled with a thickened bone and granules. DM group had a small number of granules and a thin trabecular bone wall. Interestingly, the bone thickening had not been found in the diabetic rat receiving $375 \mathrm{mg} / \mathrm{kg}$. of CSN1S2
(Fig. 4.I). The granules began to form in the trabecular bone hole of DMM375 and were still observed in the DMM750 and DMM1500. There was a trabecular bone wall thickening in DMM375, DMM750, and DMM1500. The granules formation and a thickened trabecular bone wall in them were almost similar to the control rats receiving three kinds of CSN1S2 doses (Fig. 4.III). Moreover, the trabecular bone holes were present in various locations of DMM750 and DMM1500 as well (Fig. 4.I). 


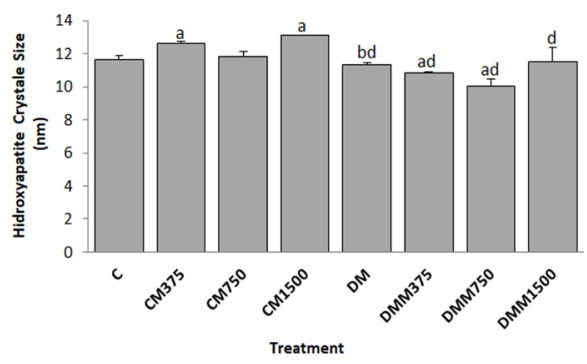

Figure 5. The X-Ray diffraction of hydroxyapatite crystals size was analyzed by XRD.

a) $P<0.05$ in comparison with control group; b) $P<0.05$ in comparison with $\mathrm{CM} 375$; d) $P<0.05$ in comparison with $\mathrm{CM} 1500$. c) control rat group receiving $0 \mathrm{mg} / \mathrm{kg}$ BW of CSN1S2 protein, CM375: control rat group receiving $375 \mathrm{mg} / \mathrm{kg}$ BW of CSN1S2 protein; CM750: control rat group receiving $750 \mathrm{mg} / \mathrm{kg}$ BW of CSN1S2 protein: CM1500: control rat group receiving $1500 \mathrm{mg} / \mathrm{kg}$ BW of CSN1S2 protein; DM: T2DM rat group receiving $0 \mathrm{mg} / \mathrm{kg}$ BW of CSN1S2 protein: DMM375: T2DM rat group receiving $375 \mathrm{mg} / \mathrm{kg}$ BW of CSN1S2 protein; DMM750: T2DM rat group receiving $750 \mathrm{mg} /$ kgBW of CSN1S2 protein; DMM1500: T2DM rat group receiving $1500 \mathrm{mg} / \mathrm{kg}$ BW of CSN1S2 protein.

The DMM375 had the layered topography of the trabecular bone surface. This layered topography was dominant in the trabecular bone surface of DMM750 and DMM1500 (Fig. 4.II).

\section{Histomorphometry of the femoral bone}

The Caprine CSN1S2 protein administration to the control rat significantly changed the histomorphometry parameters measured in this study $(P<0.05)$, see Table 1. The bone volume, BV/TV, and trabecular thickness were decreased in control rat receiving $375 \mathrm{mg} / \mathrm{kg} \mathrm{BW}$ and $750 \mathrm{mg} / \mathrm{kg} \mathrm{BW}$ of CSN1S2 protein. The trabecular spacing of CM750 and CM1500 rat groups were lower than control. However, the Tb.Sp of CM375 was higher than the control rats with and without CSN1S2 treatment. The trabecular thickness of CM1500 rat group was higher than control, CM375, and CM750. We reported that diabetic rats had significant changes as compared to the control $(P<0.05)$. They underwent an elevated value of BV, BV/TV, Tb.Th, and Tb.Sp. The BV, BV/TV, $\mathrm{Tb} . \mathrm{Th}$, and $\mathrm{Tb} . \mathrm{Sp}$ of diabetic rats turned to decrease as the $375 \mathrm{mg} / \mathrm{kg} \mathrm{BW}$ of CSN1S2 was administered. In the $750 \mathrm{mg} / \mathrm{kg} \mathrm{BW}$ and $1500 \mathrm{mg} / \mathrm{kg} \mathrm{BW}$ of CSN1S2 treatment, the diabetic rats had a lowered Tb.Th and Tb.Sp. Interestingly the CSN1S2 of $1500 \mathrm{mg} / \mathrm{kg} \mathrm{BW}$ administration significantly raised the $\mathrm{BV}$ and $\mathrm{BV} / \mathrm{TV}$ of diabetic rats compared with the control or DM group.

\section{Hydroxyapatite crystal of the femoral bone}

The hydroxyapatite crystals size of CM375 and CM1500 were bigger than that of $\mathrm{C}$ group $(P<0.05)$ (Fig. 5). However, diabetes mellitus rats demonstrated downward trend in hydroxyapatite crystals size although it was not significantly different from the $\mathrm{C}$ group (P>0.05). The $1500 \mathrm{mg} / \mathrm{kg} \mathrm{BW}$ dose of CSN1S2 administration could improve the hydroxyapatite crystal size of diabetes mellitus rats to the value of the control group $(P>0.05)$.

\section{DISCUSSIONS}

The resorption of bone tissue and formation of new bone tissue are the two antagonistic processes in bone remodeling regulated by osteoclasts and osteoblasts, respectively. If the activity of osteoclasts is faster than osteoblasts, the bones will have lower mineral density that lead to higher risk of bone fracture (Dimitriou et al., 2011). T2DM has direct negative effects on bone cells leading to risk factors for fractures. Previous study reported that T2DM individuals had an increased risk of hip fracture (Tebé et al., 2019). One of the causes of

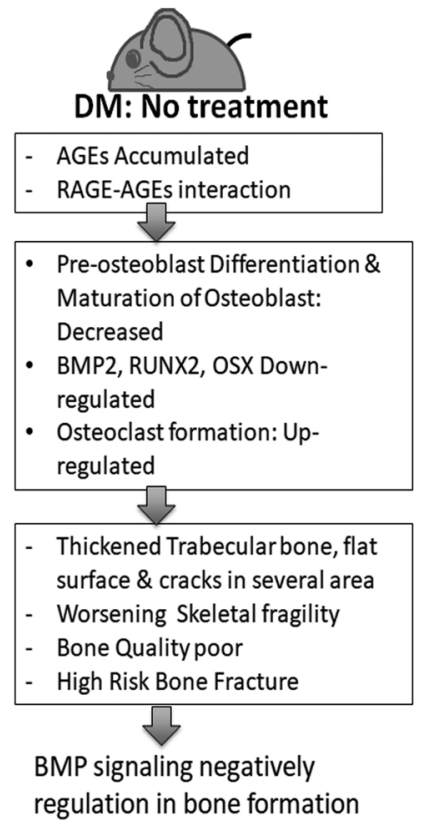

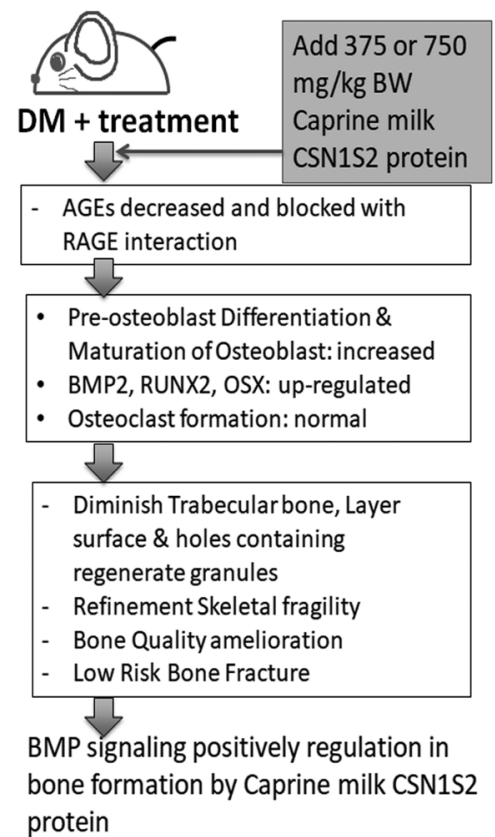

protein 
Table 1. The histomorphometry of head femoral bone in control and treatment groups measured by SEM and BoneJ software.

\begin{tabular}{|c|c|c|c|c|c|c|c|c|}
\hline Parameters & C & CM375 & CM750 & CM1500 & $\mathrm{DM}$ & DMM375 & DMM750 & $\begin{array}{l}\text { DMM } \\
1500\end{array}$ \\
\hline BV & $\begin{array}{l}556.243 \pm \\
7.895\end{array}$ & $\begin{array}{l}445.586 \pm \\
5.814^{a}\end{array}$ & $\begin{array}{l}474.274 \pm \\
43.017^{a}\end{array}$ & $\begin{array}{l}561.925 \pm \\
6.268\end{array}$ & $\begin{array}{l}688.414 \pm \\
.047^{a}\end{array}$ & $\begin{array}{l}517.189 \pm \\
2.159 \text { ae }\end{array}$ & $\begin{array}{l}598.666 \pm \\
130.154\end{array}$ & $\begin{array}{l}758.884 \pm \\
7.026^{\mathrm{ae}}\end{array}$ \\
\hline BV/TV (\%) & $\begin{array}{l}0.665 \pm \\
0.009\end{array}$ & $\begin{array}{l}0.533 \pm \\
0.006^{a}\end{array}$ & $\begin{array}{l}0.567 \pm \\
0.051^{a}\end{array}$ & $\begin{array}{l}0.674 \pm \\
0.017\end{array}$ & $\begin{array}{l}0.824 \pm \\
0.002^{a}\end{array}$ & $\begin{array}{l}0.619 \pm \\
0.002^{\mathrm{ae}}\end{array}$ & $\begin{array}{l}0.717 \pm \\
0.156\end{array}$ & $\begin{array}{l}0.919 \pm \\
0.036^{\mathrm{ae}}\end{array}$ \\
\hline Tb.Th $(\mu \mathrm{m})$ & $\begin{array}{l}2.834 \pm \\
0.045\end{array}$ & $\begin{array}{l}1.862 \pm \\
0.069 a\end{array}$ & $\begin{array}{l}1.534 \pm \\
0.598^{a}\end{array}$ & $\begin{array}{l}3.127 \pm \\
0.023^{a}\end{array}$ & $\begin{array}{l}3.940 \pm \\
0.003^{a}\end{array}$ & $\begin{array}{l}2.794 \pm \\
0.055^{\mathrm{e}}\end{array}$ & $\begin{array}{l}2.717 \pm \\
0.722^{e}\end{array}$ & $\begin{array}{l}3.121 \pm \\
0.016^{\mathrm{e}}\end{array}$ \\
\hline Tb.Sp ( $\mu \mathrm{m})$ & $\begin{array}{l}0.368 \pm \\
0.022\end{array}$ & $\begin{array}{l}0.788 \pm \\
0.004^{a}\end{array}$ & $\begin{array}{l}0.248 \pm \\
0.029 a\end{array}$ & $\begin{array}{l}0.310 \pm \\
0.013^{a}\end{array}$ & $\begin{array}{l}0.837 \pm \\
0.002^{a}\end{array}$ & $\begin{array}{l}0.289 \pm \\
0.011^{\mathrm{ae}}\end{array}$ & $\begin{array}{l}0.336 \pm \\
0.129 \mathrm{e}\end{array}$ & $\begin{array}{l}0.312 \pm \\
0.007 \mathrm{ae}\end{array}$ \\
\hline SMI & $\begin{array}{l}2.779 \pm \\
0.313\end{array}$ & $\begin{array}{l}3.460 \pm \\
0.005^{a}\end{array}$ & $\begin{array}{l}3.669 \pm \\
0.294^{a}\end{array}$ & $\begin{array}{l}2.138 \pm \\
0.008^{a}\end{array}$ & $\begin{array}{l}1.547 \pm \\
0.052^{a}\end{array}$ & $\begin{array}{l}3.387 \pm \\
0.114^{\mathrm{ae}}\end{array}$ & $\begin{array}{l}3.440 \pm \\
0.337 \mathrm{ae}\end{array}$ & $\begin{array}{l}2.721 \pm \\
0.006^{\mathrm{eg}}\end{array}$ \\
\hline
\end{tabular}

Note: Data was presented as mean \pm standard of deviation. BV: bone volume; BV/TV: bone volume/trabecular volume; Tb.Th: trabecular thickness; Tb.Th: trabecular spacing; SMI: structure model index; \%; percentage; $\mu \mathrm{m}$ : micromolar; C: control (healthy rats without any treatment); CM375: healthy rats received CSN1S2 at dose of $375 \mathrm{mg} / \mathrm{kg}$ BW; CM750: healthy rats received CSN1S2 at dose of $750 \mathrm{mg} / \mathrm{kg}$ BW; CM1500: healthy rats received CSN1S2 at dose of $1500 \mathrm{mg} / \mathrm{kg}$ BW treatment; DM; type 2 diabetic rats; DMM375: type 2 diabetic rats supplemented with CSN1S2 at dose of 375 mg/kg BW; DMM750: type 2 diabetic rats supplemented with CSN1S2 at dose of 750 mg/kg BW; DMM1500: type 2 diabetic rats supplemented with CSN1S2 at dose of $1500 \mathrm{mg} / \mathrm{kg} \mathrm{BW;}{ }^{a}<0.05$ in comparison with control group; $P<0.05$ in comparison with diabetes mellitus rat group; $9 P<0.05$ in comparison with DMM750 group.

bone damage in diabetic people is the increase in AGEs accumulation due to the dysregulation of blood glucose level (Brownlee, 2001). Other study has demonstrated increased AGEs content in the bone tissue of T2DM rat model as well (Campbell et al., 2016). In this study, serum AGEs increased significantly in the DM compared to control. This showed that hyperglycemia in diabetes mellitus triggered the production of AGEs in the serum and a decrease in sRAGE. This study is consistent with previous findings that AGEs increased in T2DM, while sRAGE decreased (Abdulle et al., 2019).The formation of AGEs in bone matrix will increase the rate of apoptosis of osteoblasts and its precursor cells (Picke et al., 2019).

The osteoblasts differentiation is regulated by several growth factors and cytokines. BMP2, a member of BMP family, is an important osteoinductive growth factor (Sun et al., 2015). BMP2 promotes the proliferation and osteogenic differentiation of mesenchymal stem cells by regulating RUNX2 and OSX expression. RUNX2 and OSX are the growth factors that are expressed during and after differentiation into osteoblasts (Nakashima et al., 2002). BMP2 is known to control the RUNX2 expression and functions through Smad signaling (Wu, C-J, Lu, 2008). The downstream of RUNX2 during osteoblast differentiation is OSX (Nakashima et al., 2002). However, other studies revealed that OSX expression can be dependent on or independent of RUNX2 activity (Sinha \& Zhou, 2013).

Previous study reported that the RUNX2 expression was suppressed in high-fat and high-glucose conditions (Wu et al., 2019). High glucose condition and AGEs treatment in human osteoblasts demonstrated reduced expression of RUNX2 and OSX (Miranda et al., 2016). The reduced RUNX2 and OSX protein expression were observed in the mouse stromal cell line ST2 (differentiated into osteoblast-like cells) treated with AGEs as well (Okazaki \& Yamaguchi, 2012). Our data in Fig. 6 showed that BMP signaling stimulate the regulation of bone formation in diabetic rats by Caprine milk CNS1S2 protein that had a high level of serum AGEs also had the down-regulated expression of BMP2, RUNX2, and OSX. Moreover, the number of osteoblasts and osteoclasts were decreased and increased, respectively. Interestingly, this Caprine CSN1S2 protein treatment de- creased AGEs not only in control rats but also in diabetic rats. The reduction of serum AGEs level was along with the up-regulated expressions of BMP2, RUNX2 and OSX in CSN1S2 protein-treated diabetic rats. As previously stated, those osteogenic genes expressions are correlated to the osteoclast and osteoblast number, both of which are types of bone cells that keep forming and reforming bone tissue. The administration of CSN1S2 protein at the dose of 375 and $750 \mathrm{mg} / \mathrm{kg} \mathrm{BW}$ was able to reduce the osteoclast number in diabetic rats and induce the osteoblast differentiation both in control and diabetic rats. Therefore, the Caprine CSN1S2 protein may play a role in bone formation through induction of the BMP2, RUNX2, and OSX expression.

Caspase-3 is a critical enzyme for apoptosis and cell survival. An inappropriate apoptosis of osteoblasts/osteocytes accounted for the imbalance of bone remodeling in osteoporosis. In diabetes condition, the Caspase- 3 expression was getting higher than the control (He et al., 2018). In this study, the diabetic rats had an elevated Caspase-3 expression. The 375, 750, and $1500 \mathrm{mg} / \mathrm{kg}$ BW of CSN1S2 protein doses were able to weaken the Caspase- 3 expression in diabetic rats.

The results of this study suggest that CSN1S2 protein is a smart molecule with its anti-glycation properties. The anti-glycation mechanism occurs through the increasing of sRAGE that will bind to AGEs, therefore serum AGEs will change to a lower level. Our previous study showed that the CSN1S2 protein acted as AGEsRAGE inhibitor that disrupted the signaling transduction cascade (Fatchiyah et al., 2015). This study proves that CSN1S2 may be a candidate for a new anti-glycation molecule.

The change of different directions and in different intensity of bone is able to change loading patterns that can alter structural density and increase the degree of structural orientation (Osterhoff et al., 2016). The mesostructure of control rats demonstrated rod-like trabeculae with minimal holes in control rat (Noor \& Setiawan, 2013). The CSN1S2 treatment triggered the thickening of trabecular bone wall and granule formation in control rat. Our research indicated that the administration of CSN1S2 induced the bone growth. This finding was supported by the hydroxyapatite crystal size, which tended to increase in CSN1S2-treated control rat. Meanwhile, 
the diabetes mellitus rat showed granules thickening that filled the trabecular bone holes. The administration of CSN1S2 at the dose of 750 and $1500 \mathrm{mg} / \mathrm{kg} \mathrm{BW}$ in diabetic rat was able to improve the granules and minimize the holes as in control rat. It indicated that CSN1S2 treatment could restore the trabecular bone mesostructure of diabetic rats closer to the healthy bone structure. This study extends the previous findings that revealed the bone anabolic properties of CSN1S2 (Fatchiyah \& Setiawan, 2015) through the mechanism of RAGE receptor modulation (Bia et al., 2015), as well as pre-osteoblast cell proliferation modulation (Chotimah et al., 2015).

The BV, BV/TV, and Tb.Th of CSN1S2-treated control rats (CM375 and CM750) decreased. This finding was in agreement consistent with our previous findings that CSN1S2 caused decreases in these parameters (Fatchiyah et al., 2015). The $1500 \mathrm{mg} / \mathrm{kg} \mathrm{BW}$ of CSN1S2-treated control rats showed a rise in Tb.Th and a significant decrease in Tb.Sp and SMI compared to controls. This indicates that the best anabolic effect occurred in the $1500 \mathrm{mg} / \mathrm{kg}$ BW of CSN1S2 administration. The $1500 \mathrm{mg} / \mathrm{kg} \mathrm{BW}$ of CSN1S2 increases the trabecular thickness, suppresses porous, and changes rodlike structures into plate-like.

In diabetes mellitus rats, there was an increase in BV, BV/TV, Tb.Th, Tb.Sp and a significant decrease in SMI compared to control rats $(P<0.05)$. This showed that changes in volume of bone, percentage of bone volume to total volume, trabecular thickness, and increased porosity had taken place in diabetes mellitus. The rod-like structures alteration to plate-like was induced by hyperglycemia. The possible mechanism happens through the glycation reaction that triggers oxidative stress and inhibits bone mineralization (Hofbauer et al., 2007). Hyperglycemia affects directly through a decrease in formation and motility of osteoclast so that there will be difficulties in reaching the micro-fractures and repairing the osteoclasts. Hyperglycemia decreases the number of osteoblasts as well (Willett et al., 2014).

The main limitation of this study is the unchanged blood glucose level of T2DM rats after a Caprine CSN1S2 protein treatment. The CSN1S2 protein was not able to lower the high blood glucose level of T2DM rats in 28 days of treatment. However, CSN1S2 protein reduced the serum AGEs level of T2DM rats implicated in the up-regulated expressions of BMP2, RUNX2, and OSX. This indicates that CSN1S2 does not have a hypoglycemic effect, but works to inhibit the formation of AGEs, modulation of osteoblast signals, and repair of mesostructure and bone crystals. The absence of this hypoglycemic effect makes CSN1S2 a smart molecule to avoid potential hypoglycemia as a side effect in the treatment of diabetic patients (He et al., 2019).

The trabecular repairing mechanism in DM rat was showed by the ability of Caprine Milk CSN1S2 protein to decrease the AGEs accumulation, the mechanism related with bone morphogenetic protein (BMP) signaling pathway for osteoblast related bone formation. Improvement of bone formation was indicated by normalizing of trabecular thickness, covering of the trabecular surface by granules, decreasing trabecular porosity, and improving the structural index towards the rod-like trabeculae. Nano-structurally, this mesostructure alteration involves at least a change in hydroxyapatite crystals. The 375, 750 , and $1500 \mathrm{mg} / \mathrm{kg}$ BW of Caprine CSN1S2 protein administration in diabetic rats were able to repair bone, in the form of $\mathrm{Tb}$. Th controlling similar to the $\mathrm{C}$ group. The porosity improvement was found in diabetic rats receiving 750 and $1500 \mathrm{mg} / \mathrm{kg} \mathrm{BW}$ of CSN1S2, reaching a value comparable to the control group. This indicates that both of CSN1S2 doses can induce bone regeneration in the form of controlling values in healthy bones. This is supported by the change of SMI value of diabetic rats close to the value in healthy rats. Administration of high dose CSN1S2 at T2DM rats leads to improvement of SMI value compared to the others. This result is consistent with previous research suggesting that Caprine CSN1S2 protein acts as an anti-osteoporosis in rat model of rheumatoid arthritis (Fatchiyah et al., 2015). This study proposes that the Caprine CSN1S2 protein has a role as an anti-osteoporosis in T2DM rat model via bone morphogenetic protein (BMP) pathway.

\section{CONCLUSIONS}

The Caprine CSN1S2 protein has an osteoprotective effect against the T2DM rats through the inhibition of glycation pathway and the improvement of bone mesostructure and histomorphometry. Thus, Caprine CSN1S2 protein can be used as an alternative nutrition in preventing T2DM complications.

\section{Data Availability}

The data used to support the findings of this study are available from the corresponding author upon request.

\section{Conflicts of Interest}

The authors declare that there is no conflict of interest regarding the publication of this paper.

\section{Author Contributions}

Fatchiyah Fatchiyah and Bambang Setiawan contributed to the conception and design of the experiments, acquisition of data, analysis, and data interpretation, drafting article, critically revising the article and final approval of the version to be published. Tomohiko Sasase and Takeshi Ohta contributed to data interpretation and reviewing the manuscript.

\section{Acknowledgments}

We give thanks to Dr. drg. Arif Rachman, MM., MTr., Hanla., Sp.Pros., at Dr. Ramelan Naval Hospital, Surabaya, and Dr. dr. Indri Laksmi Putri, Sp.BP-RE (KKF) at Airlangga University Hospital, Surabaya for providing the BMP2, RUNX2, and OSX antibodies. Gratitude sent to Anna Safitri, Ph.D (UB) for comments on the manuscript, Rista Nikmatu Rochmah and Hazna Noor Meidina for laboratory assistant. We thank the Molecular Biology Laboratory of Biosains Institute, Brawijaya University for providing the laboratory facilities.

\section{REFERENCES}

Abdulle A, Inman CK, Saleh A, Noshi M, Galani D, Abdelwareth L, Alsafar H, Elfatih A, Al H, Ali R, Li H, Ramasamy R, Marie A, Benbarka MM (2019) Metabolic dysfunction in Emirati subjects in Abu Dhabi: Relationship to levels of soluble RAGEs. J. Clin.Trans. Endocrinol. 16: 100192. https://doi.org/10.1016/j.jcte.2019.100192

Adil C, Aydın T, Taşpınar Ö, Kızıltan H, A Eriş AH, Hocaoglu IT, Poşul S, Kepekci M, Denizli E, and Güler M (2015) Bone mineral density evaluation of patients with type 2 diabetes mellitus. J. Phys. Ther. Sci. 27: 179-182. https://doi.org/10.1589/jpts.27.179

Agustina V, Setiawan B, Fatchiyah F (2015) Acute toxicity of Caprine alpha S2-casein protein on the microstructures and mineral profiles of rat ileum. Asian Pacific J. Trop. Dis. 5: 721-725. https://doi. org/10.1016/S2222-1808(15)60920-3 
Bia RR, Virgirinia, RP, Setiawan B, Soewondo A, Fatchiyah F (2015) Goat milk CSN1S2 is able to decrease the severity scoring, TNF- $\alpha$, and RAGE expression in complete Freund's adjuvant-induced rheumatoid arthritis model of rats. Biomarkers Genomic Med. 7: 64-71. https://doi.org/10.1016/j.bgm.2015.02.001

Brownlee M (2001) Biochemistry and molecular cell biology of diabetic complications. Nature 414: 813-820. https://doi. org $/ 10.1038 / 414813 a$

Campbell GM, Tiwari S, Picke AK, Hofbauer C, Rauner M, Morlock MM, Hofbauer LC, Glüer CC (2016) Effects of insulin therapy on porosity, non-enzymatic glycation and mechanical competence in the bone of rats with type 2 diabetes mellitus. Bone 91: 186-193. https://doi.org/10.1016/j.bone.2016.08.003

Chotimah C, Ciptadi G, Setiawan B, Fatchiyah F (2015) CSN1S2 protein of goat milk inhibits the decrease of viability and increases the proliferation of MC3T3E1 pre-osteoblast cell in methyl glyoxal exposure. Asian Pacific J. Trop. Dis. 5: 219-223. https://doi. org/10.1016/S2222-1808(14)60657-5

Devangelio E, Santilli F, Formoso G, Ferroni P, Bucciarelli L, Michetti N, Clissa C, Ciabattoni G, Consoli A, Davì G (2007) Soluble RAGE in type 2 diabetes: Association with oxidative stress. Free Radic. Biol. Med. 43: 511-518. https://doi.org/10.1016/j.freeradbiomed.2007.03.015

Dimitriou R, Jones E, McGonagle D, Giannoudis P V(2011) Bone regeneration: Current concepts and future directions. BMC Med. 9: 1-10. https://doi.org/10.1186/1741-7015-9-66

Dong XN, Qin A, Xu J, Wang X (2011) In situ accumulation of advanced glycation endproducts (AGEs) in bone matrix and its correlation with osteoclastic bone resorption. Bone 49: 174-183. https:// doi.org/10.1016/j.bone.2011.04.009

Fatchiyah, Zubair M, Shima Y, Oka S, Ishihara S, Fukui-Katoh Y, Morohashi KI (2006) Differential gene dosage effects of Ad4BP/SF-1 on target tissue development. Biochem. Biophys. Res. Commun. 341: 1036-1045. https://doi.org/10.1016/j.bbrc.2006.01.058

Fatchiyah F, Setiawan B, Suharjono S, Noor Z (2015) The anti-osteoporosis effects of CSN1S2 protein of goat milk and yoghurt on a complete Freund's adjuvant-induced rheumatoid arthritis model in rats. Biomarkers Genomic Med. 7: 139-146. https://doi.org/10.1016/j. bom.2015.10.001

Fatchiyah F, Hardiyanti F, Widodo N (2015) Selective inhibition on RAGE-binding AGEs required by bioactive peptide alpha-S2 case in protein from goat Ethawah breed milk: Study of biological modeling. Acta Informatica Medica 23: 90-96. https://doi.org/10.5455/ aim.2015.23.90-96

Fatchiyah F, Rohmah RN, Triprisila LF, Ohta T, Meidinna HN (2020) The Caprine casein-alpha-S2 protein modulates the molecular mechanism of insulin signal transduction in type 2 diabetes rat. Acta Biochim. Pol. 67: 401-408. https://doi.org/10.18388/abp.2020_5357

Follet H, Viguet-Carrin S, Burt-pichat B, De B, Bala Y, Gineyts E, Munoz F, Arlot M, Boivin G, Chapurlat RD, Delmas PD, Bouxsein ML (2011) Effects of preexisting microdamage, collagen crosslinks, degree of mineralization, age, and architecture on compressive mechanical properties of elderly human vertebral trabecular bone. J. Orthopaedic Res. 29: 481-488. https://doi.org/10.1002/jor.21275

Gateva AT, Assyov YS, Tsakova AD, Kamenov ZA (2019) Serum AGEs and sRAGE levels are not related to vascular complications in patients with prediabetes. Diabetes Metabolic Syndrome: Clin. Res. Rev. 13: 1005-1010. https://doi.org/10.1016/j.dsx.2019.01.014

Gkogkolou P, Böhm M (2012) Advanced glycation end products: Keyplayers in skin aging? Dermato-Endocrinol. 4: 259-270. https://doi. org/10.4161/derm.22028

Hayatullina Z, Muhammad N, Mohamed N, Soelaiman IN (2012) Virgin coconut oil supplementation prevents bone loss in osteoporosis rat model. Evidence-Based Complement. Alter. Med. 2012: https://doi. org $/ 10.1155 / 2012 / 237236$

He X, Sun J, Huang X (2018) Expression of caspase-3, Bax and Bcl2 in hippocampus of rats with diabetes and subarachnoid hemorrhage. Exp. Ther. Med. 15: 873-877. https://doi.org/10.3892/ etm.2017.5438

He JH, Chen LX, Li H (2019) Review: Progress in the discovery of naturally occurring anti-diabetic drugs and in the identification of their molecular targets. Fitoterapia 134: 270-289. https://doi. org/10.1016/i.fitote.2019.02.033

Hie M, Iitsuka N, Otsuka T, Tsukamoto I (2011) Insulin-dependent diabetes mellitus decreases osteoblastogenesis associated with the inhibition of Wnt signaling through increased expression of Sost and Dkk1 and inhibition of Akt activation. Int. J. Mol. Med. 28: 455-462. https://doi.org/10.3892/ijmm.2011.697

Hofbauer LC, Brueck CC, Shanahan CM, Schoppet M, Dobnig H (2007) Vascular calcification and osteoporosis - From clinical observation towards molecular understanding. Osteopor. Int. 18: 251259. https://doi.org/10.1007/s00198-006-0282-z

Hsia S, Lee W, Yen G, Wu C (2016) Capsaicin, an active ingredient from chilli peppers, attenuates glycative stress and restores SRAGE levels in diabetic rats. J. Funct. Foods 21: 406-417. https://doi. org/10.1016/j.jff.2015.11.043
Issa C, Zantout MS, Azar ST (2011) Osteoporosis in Men with Diabetes Mellitus. J. Osteopor. 651867. https://doi.org/10.4061/2011/651867

Karim L, Vashishth D (2012) Heterogeneous glycation of cancellous bone and its association with bone quality and fragility. PLoS One 7: e35047. https://doi.org/10.1371/journal.pone.0035047

Karim L, Moulton J, Vliet M Van, Velie K, Robbins A (2018) Bone microarchitecture, biomechanical properties, and advanced glycation end-products in the proximal femur of adults with type 2 diabetes. Bone 114: 32-39. https://doi.org/10.1016/j.bone.2018.05.030

Kerkeni M, Saïdi A, Bouzidi H, Ben S, Hammami M (2012) Elevated serum levels of AGEs, sRAGE, and pentosidine in Tunisian patients with severity of diabetic retinopathy. Microvasc. Res. 84: 378383. https://doi.org/10.1016/j.mvr.2012.07.006

Kazakia GJ, Hyun B, Burghardt AJ, Krug R, Newitt DC, de Papp AE, Link T, Majumdar S (2008) In vivo determination of bone structure in postmenopausal women: a comparison of HR-pQCT and high-field MR imaging. J. Bone Miner Res. 23: 463-474. https://doi. org $/ 10.1359 /$ ibmr.071116

Lalla E, Stern DM, Schmidt AM, Lalla E, Lamster IB, Feit M, Huang L, Spessot A, Qu W, Kislinger T, Lu Y, Stern DM, Schmidt AM (2000) Blockade of RAGE suppresses periodontitis-associated bone loss in diabetic mice Find the latest version: Blockade of RAGE suppresses periodontitis-associated bone loss in diabetic mice. J. Clin. Invest. 105: 1117-1124. https://doi.org/10.1172/JCI8942

Miranda C, Giner M, José Montoya M, Vázquez MA, Miranda MJ, Pérez-Cano R (2016) Influence of high glucose and advanced glycation end-products (ages) levels in human osteoblast-like cells gene expression. BMC Musculoskeletal Disorders 17: 1-9. https://doi. org/10.1186/s12891-016-1228-z

Moree SS, Kavishankar GB, Rajesha J (2013) Antidiabetic effect of secoisolariciresinol diglucoside in streptozotocin-induced diabetic rats. Phytomedicine 20: 237-245. https://doi.org/10.1016/j. phymed.2012.11.011

Nakashima K, Zhou X, Kunkel G, Zhang Z, Deng JM, Behringer RR and de Crombrugghe B (2002) The novel zinc finger-containing transcription factor osterix is required for osteoblast differentiation and bone formation. Cell 108: 17-29. https://doi.org/10.1016/ S0092-8674(01)00622-5

Noor Z, Setiawan B (2013) Subchronic inhalation of coal dust particulate matter 10 changes bone mesostructure, mineral element levels and turnover markers in rats. Biomarkers Genomic Med. 3: 153-158. https://doi.org/10.5455/jeim.150213.or.060

Nyman JS, Roy A, Tyler JH, Acuna RL, Gayle HJ, Wang X (2007) Age-related factors affecting the post-yield energy dissipation of human cortical bone. J. Orthop. Res. 25: 646-655. https://doi. org/10.1002/jor.20337

Oh SR, Sul OJ, Kim YY, Kim HJ, Yu R, Suh JH, Choi HS (2010) Saturated fatty acids enhance osteoclast survival. J. Lipid Res. 51: 892-899. https://doi.org/10.1194/jlr.M800626

Okazaki K, Yamaguchi T (2012) Advanced glycation end products (AGEs), but not high glucose, inhibit the osteoblastic differentiation of mouse stromal ST2 Cells through the suppression of osterix expression, and inhibit cell growth and increasing cell apoptosis. Calcif Tissue Int. 91: 286-296. https://doi.org/10.1007/s00223-012-9641-2

Osterhoff G, Morgan E, Shefelbine SJ, Karim L, McNamarae LM, and Augat P (2016) Bone mechanical properties and changes with osteoporosis. Injury Int. J. Care Injured 47(Suppl 2): S11-S20. https:// doi.org/10.1016/S0020-1383(16)47003-8

Parfitt AM, Drezner MK, Glorieux FH, Kanis JA, Malluche H, Meunier PJ, Ott SM, Recker RR (1987) Bone histomorphometry: standardization of nomenclature, symbols, and units. Report of the ASBMR Histomorphometry Nomenclature Committee. J. Bone Mineral Res. 2: 595-609. https://doi.org/10.1002/jbmr.5650020617

Picke AK, Campbell G, Napoli N, Hofbauer LC, Rauner M (2019) Update on the impact of type 2 diabetes mellitus on bone metabolism and material properties. Endocrine Connections 8: R55-R70. https://doi.org/10.1530/EC-18-0456

Poundarik AA, Wu PC, Evis Z, Sroga GE, Ural A, Rubin M, Vashishth D (2015) A direct role of collagen glycation in bone fracture. J. Mech. Behav. Biomed. Mat. 52: 120-130. https://doi.org/10.1016/j. jmbbm.2015.08.012

Seeman E, Delmas PD (2006) Bone quality the material and structural basis of bone strength and fragility. N. Engl. J. Med. 354: 22502261. https://doi.org/10.1056/NEJMra053077

Sinha KM, Zhou X (2013) Genetic and molecular control of osterix in skeletal formation. J. Cell. Biochem. 114: 975-984. https://doi. org/10.1002/jcb.24439

Stirban A, Gawlowski T, Roden M (2014) Vascular effects of advanced glycation endproducts: Clinical effects and molecular mechanisms. Mol. Metabol. 3: 94-108. https://doi.org/10.1016/j.molmet.2013.11.006

Sun J, Li J, Li C, Yu Y (2015) Role of bone morphogenetic protein-2 in osteogenic differentiation of mesenchymal stem cells. Mol. Med. Rep. 12: 4230-4237. https://doi.org/10.3892/mmr.2015.3954 
Takizawa M, Kameyama K, Maruyama M, Ishida H (2003) Bone loss in type 2 diabetes mellitus-diabetic osteopenia. Nibon Rinsho 61: 287-291

Tebé C, Martínez-Laguna D, Carbonell-Abella C, Reyes C, Moreno V, Diez-Perez A, Collins GS, Prieto-Alhambra D (2019) The association between type 2 diabetes mellitus, hip fracture, and post-hip fracture mortality: a multi-state cohort analysis. Osteoporosis Int. 30: 2407-2415. https://doi.org/10.1007/s00198-019-05122-3

Thielen NGM, Kraan PM Van Der, Caam APM Van (2019) TGFb/ BMP signaling pathway in cartilage homeostasis. Cells 8: 1-30. https://doi.org/10.3390/cells8090969

Tsuji K, Cox K, Bandyopadhyay A, Harfe BD, Tabin CJ, Rosen V (2008) BMP4 is dispensable for skeletogenesis and fracture-healing in the limb. J. Bone Joint Surgery - Series A 90: 14-18. https://doi. org/10.2106/JBJS.G.01109

Willett TL, Pasquale J, Grynpas MD (2014) Collagen modifications in postmenopausal osteoporosis: advanced glycation endproducts may affect bone volume, structure and quality. Curr. Osteoporosis Rep. 12: 329-337. https://doi.org/10.1007/s11914-014-0214-3

Wittrant Y, Gorin Y, Woodruff K, Horn D, Abboud HE, Mohan S and Abboud-Werner SL (2008) High d(+)glucose concentration inhibits RANKL-induced osteoclastogenesis. Bone 42: 1122-1130. https://doi.org/10.1016/j.bone.2008.02.006

Wu, C-J, Lu H-K (2008) Smad signal pathway in BMP-2-induced osteogenesis - a mini review. J. Dent. Sci. 3: 13-21

Wu M, Chen G, Li YP (2016) TGF- $\beta$ and BMP signaling in osteoblast, skeletal development, and bone formation, homeostasis and disease. Bone Res. 4: 1-18 https://doi.org/10.1038/boneres.2016.9

Wu X, Zhang Y, Xing Y, Zhao B, Zhou C, Wen Y, Xu X (2019) High-fat and high-glucose microenvironment decreases Runx2 and TAZ expression and inhibits bone regeneration in the mouse 11 Medical and Health Sciences 1103 Clinical Sciences. J. Orthopaedic Surgery Res. 14: 1-9. https://doi.org/10.1186/s13018-019-1084-2

Yamanaka JS, Yanagihara GR, Carlos BL, Ramos J, Brancaleon BB, Macedo AP, Issa JPM, Shimano AC (2018) A high-fat diet can affect bone healing in growing rats. J. Bone Mineral Metab. 36: 255263. https://doi.org/10.1007/s00774-017-0837-4 